\title{
Designed Transfer of Specific Immune Responses with Bone Marrow Transplantation
}

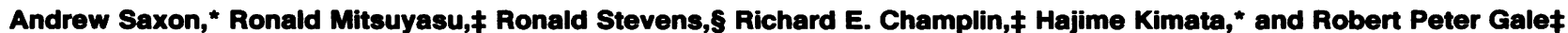 \\ Divisions of Clinical Immunology/Allergy* and Hematology/Oncology, $\ddagger$ Departments of Medicine and Microbiology and Immunology, $\S$ \\ The Jonnson Comprehensive Cancer Center, UCLA School of Medicine, Los Angeles, California 90024
}

\begin{abstract}
Bone marrow transplant donors were immunized with tetanus/ diphtheria toxoids 6-7 d before bone marrow donation to investigate the role of $B$ cell subpopulations in reconstitution of humoral immunity. Lymphoblastoid B cells spontaneously producing IgG antitetanus and/or antidiphtheria toxoid were detected in the donor marrows at the time of transplantation. Recipients rapidly demonstrated 3-90-fold increases in serum IgG antitetanus and antidiphtheria toxoid levels. Antidiphtheria fragment $A$ antibody in three donor/recipient pairs demonstrated spectrotypic identity indicating transfer of the donors' response. Reimmunization of three recipients 64-154 d after transplant revealed an IgG antibody response associated with reappearance of spontaneous antibody-producing B cells and an antidiphtheria fragment $A$ response characteristics of the donor's immune response. These observations extend the understanding of the role of $B$ cell subpopulations and provide a basis for specific modulation of immunity in the setting of bone marrow transplantation.
\end{abstract}

\section{Introduction}

Bone marrow transplantation is increasingly used to treat hematologic, neoplastic, and immune disorders (1). Bone marrow transplantation in humans also provides a unique opportunity to study reconstitution of cellular and humoral immune responses. One of the challenges in bone marrow transplantation is to determine ways to transfer more rapidly and effectively to the recipient an immune system capable of responding to environmental pathogens. Individuals receiving bone marrow transplantation are highly susceptible to infections in the early posttransplant period $(2,3)$. Most bone marrow transplant recipients, particularly those with graft versus host disease (GVHD), ${ }^{1}$ are profoundly immunodeficient for prolonged periods.

Dr. Saxon was a recipient of Allergic Diseases Academic Award AI00326 from the National Institute of Allergy and Infectious Disease. Dr. Mitsuyasu is a recipient of Clinical Investigator Award KO8CA00932 from the National Cancer Institute and Junior Clinical Faculty Fellowship (JCFA-786) from the American Cancer Society.

Address reprint requests to Dr. Saxon.

Received for publication 24 December 1985 and in revised form 28 May 1986.

1. Abbreviations used in this paper: CMV, cytomegalovirus; dip, diphtheria; GVHD, graft versus host disease; IEF, isoelectric focusing; PWM, pokeweed mitogen; tet, tetanus.

J. Clin. Invest.

(c) The American Society for Clinical Investigation, Inc.

0021-9738/86/10/0959/09 \$1.00

Volume 78, October 1986, 959-967
There have been several detailed studies of recovery of B cell function after bone marrow transplantation in animals and humans. Although B lymphocyte numbers rapidly return to normal soon after bone marrow transplantation, serum immunoglobulin levels remain low for a prolonged period (4-6). Immunoglobulin levels normalize within 6-9 mo but functional antibody responses are impaired indefinitely (6-9). In addition, the function of $\mathrm{T}$ lymphocytes is reported to be abnormal after bone marrow transplantation. This is reflected in altered proportions of $\mathrm{T}$ lymphocyte subsets where $\mathrm{T}$ helper/inducer phenotype cells are reduced and $\mathrm{T}$ cytotoxic/suppressor cells are increased. These $\mathrm{T}$ and $\mathrm{B}$ cell abnormalities are increased in individuals with GVHD $(6,10)$ and after cytomegalovirus (CMV) infection $(11,12)$.

We previously studied the types of cells and their interactions involved in the human antibody response to tetanus (tet) and diphtheria (dip) toxoids (13-17). Lymphocytes in the bone marrow and blood capable of producing antibody in vitro to these antigens were identified. We defined an in vivo activated $B$ cell (lymphoblastoid B cell), which produces specific antibody to these toxoids in the absence of other cells or factors (11). Also identified was a mitogen-inducible B cell, which required $\mathrm{T}$ helper cells in order to produce an in vitro antibody response (13). These different B cells appeared at distinct times in the bone marrow after booster immunization (17). In the present study, transplant donors were immunized with tet/dip at defined intervals prior to transplantation. The specific types of B lymphocytes transferred and the subsequent acquisition of antigen-specific humoral immune responses and memory were studied in recipients.

\section{Methods}

Immunization. Donors received a single intramuscular injection of combined, absorbed tet/dip toxoids $(0.5 \mathrm{ml})$ containing 5.0 flocculating units of tetanus toxoid and 1.0 flocculating units of diphtheria toxoid (Lederle Laboratories, Pearl River, NY). Immunization of bone marrow transplantation recipients was performed in an identical fashion at specific intervals after transplant.

Bone marrow and blood lymphocyte cultures. Bone marrow and blood samples were obtained and lymphocytes were isolated as previously described (17). Cultures were established with 1,500,000 lymphocytes in $1.5 \mathrm{ml}$ of RPMI 1640 medium supplemented with $15 \%$ fetal calf serum, glutamine $(6 \mathrm{mM})$, and gentamicin $(0.04 \mathrm{mg} / \mathrm{ml})$. Cells were cultured either alone, with pokeweed mitogen (PWM, Gibco Laboratories, Grand Island, NY) at a final concentration of $1: 100(\mathrm{vol} / \mathrm{vol})$ or with cycloheximide at $50 \mu \mathrm{g} / \mathrm{ml}$ (Sigma Chemical Co., St. Louis, MO). Cells were incubated for $7 \mathrm{~d}$ at $37^{\circ} \mathrm{C}$ in a humidified atmosphere containing $5 \%$ $\mathrm{CO}_{2}$. Cells were centrifuged and the supernatants collected and assayed for antibody and total immunoglobulin production.

Radioimmunoassays. Sera and cell culture supernatants were assayed for antitetanus (antitet) IgG and IgM, and antidiphtheria (antidip) IgG. Total IgG and IgM produced in the cultures was also measured using a solid-phase assay in microtiter plates (16). Assays for specific antitet IgG 
and IgM were analogous except the plates were initially coated with purified tetanus toxoid (kindly provided by Wyeth Laboratories, Marietta, PA) at a concentration of $1 \mathrm{mg} / \mathrm{ml}$. For each assay, a seven-point standard curve was constructed using a single antiserum of predetermined antibody content. The amount of antitet antibody in samples was calculated by comparison to this standard curve. The lower limit of this assay is $1 \mathrm{ng}$ of specific antibody per ml. Although the absolute quantity of antibody may be underestimated by this technique (14), relative proportions of antibody can be accurately determined in that we used a single standard throughout. Normal individuals who have not been booster immunized with tet/dip within 6 mo show a fourfold rise in antibody titer or achieve a level $>18 \mu \mathrm{g} / \mathrm{ml}$ of IgG antitet and $6 \mu \mathrm{g} / \mathrm{ml} \mathrm{IgG}$ antidip (18). Antidip toxoid antibodies were measured in an analogous fashion by an enzymelinked immunoassay substituting alkaline phosphatase-conjugated antihuman antibody for the iodinated anti-human antibody. The coefficient of variation in these specific antibody assays was $<10 \%$.

PWM-induced antibody synthesis was calculated by subtracting the amount detected in cultures without mitogen from the amount present in the mitogen containing cultures. The amount of antibody measured in cycloheximide-treated cultures was subtracted from the other cultures as background. Data are expressed as nanograms of antibody per $1.5 \mathrm{ml}$ of culture or micrograms of antibody per milliliter of serum.

Spectrotypic analysis of antidiphtheria fragment $A$ antibody response. Fragment A was obtained from diphtheria toxin by proteolytic nicking and gel filtration as described $(18,19)$. Purity of fragment A was confirmed by sodium dodecyl sulfate (SDS)-polyacrylamide gel electrophoresis. Agarose isoelectric focusing (IEF) was performed as described (20) with the following modifications. The gel matrix was prepared by heating a $10 \%$ sorbitol $-0.8 \%$ agarose mixture to near boiling. Bio-Rad ampholines (Bio-Rad Laboratories, Richmond, CA), 3.5-10, were added to a final concentration of $0.5 \%$. The gel mixture was poured onto the hydrophobic side of GelBond film (FMC Co., Marine Colloids Div., Bioproducts, Rockland, ME). After cooling and overnight incubation at $4^{\circ} \mathrm{C}$ in a humidified chamber, the gel was blotted to remove excess water. Sera $(5-20 \mu \mathrm{l})$ were loaded onto sample applicators and focusing was performed at $4^{\circ} \mathrm{C}$. After completion of the run, the pH of the gel was determined and the gel immediately immersed in $37^{\circ} \mathrm{C}$ saturated sodium sulfate solution. Thereafter, the gels were incubated with ${ }^{125}$ I-fragment A for 1 hour $(2,000-3,000 \mathrm{cpm} / \mathrm{ng}$ at $1 \mu \mathrm{g} / \mathrm{ml}$ in $10 \%$ bovine serum albumin-phosphate-buffered saline, $\mathrm{pH}$ 7.6). After extensive washing and subsequent drying, the gels were fixed and autoradiographed.

\section{Results}

Bone marrow transplantation donors and recipients. Nine donor/ recipient pairs were enrolled in the study; seven pairs were evaluable. Clinical features are summarized in Table I. Pair 2 was uninformative as the recipient died from infection on day 12 posttransplant. Recipient 8 was also unevaluable because of a leukemia relapse shortly posttransplant.

All recipients received bone marrow transplants from HLAA, B, C, and DR-identical, mixed lymphocyte culture nonreactive sibling donors. The experimental design was approved by the UCLA Human Subject Protection Committee and written informed consent was obtained from all individuals. Patients were adult recipients undergoing bone marrow transplantation for acute or chronic leukemia or aplastic anemia. The preparative regimen for patients with acute leukemia was cytarabine, $3 \mathrm{~g}$ / $\mathrm{m}^{2}$ intravenously every $12 \mathrm{~h}$ for eight doses followed by total body irradiation, 11.25 Gy in five fractions over $2.5 \mathrm{~d}$. Patients with chronic myelogenous leukemia received cyclophosphamide, $60 \mathrm{mg} / \mathrm{kg} / \mathrm{d}$, on days -4 and -3 , followed by total body irradiation as for acute leukemia. Aplastic anemia patients received cyclophosphamide, $50 \mathrm{mg} / \mathrm{kg} / \mathrm{d}$ for $4 \mathrm{~d}$ followed by a single 3 Gy dose of total lymphoid irradiation on the day prior to transplant. All patients received posttransplant GVHD prophylaxis
Table I. Characteristics of Patients Undergoing Bone Marrow Transplantation

\begin{tabular}{|c|c|c|c|c|c|}
\hline $\begin{array}{l}\text { Patient no. } \\
\text { UPN no. }\end{array}$ & Age & Disease* & Conditioning & $\begin{array}{l}\text { GVHDS } \\
\text { A/C }\end{array}$ & $\begin{array}{l}\text { Infection } \\
\text { (day 1-30) }\end{array}$ \\
\hline & $y r$ & & & & \\
\hline 1 & 39 & CML & $\mathrm{CTX} 60 \mathrm{mg} / \mathrm{kg} \times 2$ & $4 / 0$ & CMV-day 6 \\
\hline 372 & & & TBI 1,125 rads & & \\
\hline 3 & 44 & CML & CTX $60 \mathrm{mg} / \mathrm{kg} \times 2$ & $0 / 2$ & 0 \\
\hline 385 & & & TBI 1,125 rads & & \\
\hline 4 & 32 & AML & Ara-C $3 \mathrm{~g} / \mathrm{m}^{2} \times 8$ & $3 / 0$ & 0 \\
\hline 399 & & & TBI 1,125 rads & & \\
\hline 5 & 27 & CML & CTX $60 \mathrm{mg} / \mathrm{kg} \times 2$ & $0 / 3$ & 0 \\
\hline 409 & & & TBI 1,125 rads & & \\
\hline 6 & 19 & AA & CTX $50 \mathrm{mg} / \mathrm{kg} \times 4$ & $2 / 2$ & 0 \\
\hline 408 & & & TLI 300 rads & & \\
\hline 7 & 44 & CML & CTX $60 \mathrm{mg} / \mathrm{kg} \times 2$ & $3 / 0$ & 0 \\
\hline 420 & & & TBI 1,125 rads & & \\
\hline 9 & 21 & AA & CTX $50 \mathrm{mg} / \mathrm{kg} \times 4$ & $3 / 2$ & 0 \\
\hline 421 & & & TLI 300 rads & & \\
\hline
\end{tabular}

${ }^{*} \mathrm{CML}$, chronic myelogenous leukemia; AA, aplastic anemia; AML, acute myelogenous leukemia.

‡ CTX, cyclophosphamide-for CML, $60 \mathrm{mg} / \mathrm{kg} / \mathrm{d}$ on days -4 and -3 , or for AA, $50 \mathrm{mg} / \mathrm{kg} / \mathrm{d}$ on days -3 and -2 ; Ara-C, cytosine arabinoside-for AML $3 \mathrm{~g} / \mathrm{m}^{2}$ every $12 \mathrm{~h} \times 8$ doses; TBI, total body irradiation; TLI, total lymphoid irradiation.

$\S$ GVHD, graft versus host disease; $A / C$, acute/chronic. Patients with acute GVHD of grade 2 or greater received high-dose corticosteroid which was slowly tapered as tolerated to control symptoms: Cyclosporine, $5 \mathrm{mg} / \mathrm{kg}$ i.v. bolus on day 1 followed by $3 \mathrm{mg} / \mathrm{kg} / \mathrm{d}$ by constant i.v. infusion for $21 \mathrm{~d}$ with dose adjusted to maintain trough levels at $150 \mathrm{ng} / \mathrm{ml}$, and then $3 \mathrm{mg} / \mathrm{kg}$ orally every $12 \mathrm{~h}$ up to day 90 .

with cyclosporine administered as a $5 \mathrm{mg} / \mathrm{kg}$ intravenous loading dose followed by $2-3 \mathrm{mg} / \mathrm{kg} / \mathrm{d}$ by continuous intravenous infusion for $21 \mathrm{~d}$, the dose being adjusted to maintain trough levels of $\sim 150 \mathrm{ng} / \mathrm{ml}$. Oral cyclosporine $(3 \mathrm{mg} / \mathrm{kg}$ ) was given every $12 \mathrm{~h}$ from day 21 through 90 . Patients with grade 2 or greater GVHD received high-dose corticosteroids which were slowly tapered as tolerated to control symptoms. Clinical details are summarized in Table I. In all patients, complete engraftment was documented by cytogenetic analysis and studies of polymorphisms of red blood cells and lymphocyte antigens and isoenzymes.

Adoptive transfer of $\operatorname{IgG}$ antitetanus and diphtheria toxoid responses. Prior to booster immunization, none of the recipients tested had circulating cells capable of producing a significant in vitro specific IgG antitet (Table II) or antidip (Table III) antibody response. One donor (no. 6) had cells that spontaneously produced an IgG antibody response to dip; none showed a PWM response to either antigen. The levels of $1-2 \mathrm{ng} /$ culture observed in some PWM cultures are minimal as PWM-induced cultures from responsive cells produce between 5 and 1,000 $\mathrm{ng}$ of antitet and between 5 and $250 \mathrm{ng}$ of antidip per $1.5 \mathrm{ml}$ culture. The lack of response in the donors reflects no recent booster immunization with tet/dip toxoids (13).

Donors then received a booster tet/dip immunization and their bone marrow was tested 6-7 d later at the time of transplantation. In every instance, the transplanted bone marrow was found to contain B cells spontaneously producing IgG to tet and dip toxoids (Tables II and III). All donors subsequently dem- 
Table II. Serum and In Vitro IgG Antitetanus Toxoid Response from the Recipient and Donor after Booster Immunization of the Donor 6-7 $d$ before Bone Marrow Transplantation

\begin{tabular}{llll}
\hline Day & $\begin{array}{l}\text { Serum IgG } \\
\text { antitet } \\
\text { recipient/donor }\end{array}$ & $\begin{array}{l}\text { Lymphoblastoid IgG } \\
\text { antitet } \\
\text { recipient/donor }\end{array}$ & $\begin{array}{l}\text { PWM-inducible IgG } \\
\text { antitet } \\
\text { recipient/donor }\end{array}$ \\
\hline$\mu g / m l$ & $n g / c u l t u r e$ & $n g / c u l t u r e$
\end{tabular}

Recipient/donor pair 1

$\begin{array}{rccr}-6 & 1.0 / 5.0 & 0 / 0 & 1 / 0 \\ 0 & \text { ND/7.0 } & \text { ND/5.0 } & \text { ND/0 } \\ 14 & 77 / \mathrm{ND} & & \\ 29 & 90 / 94 & & \end{array}$

Recipient/donor pair 3

$\begin{array}{rccc}-6 & 9.6 / 48 & 0 / 0 & 0 / 1 \\ 0 & \text { ND/64 } & \text { ND/32 } & \text { ND/32 } \\ 5 & 18 / \mathrm{ND} & & \\ 12 & 83 / \mathrm{ND} & & \\ 19 & 114 / \mathrm{ND} & & \\ 27 & 82 / \mathrm{ND} & & \\ 33 & 64 / 38 & & \end{array}$

Recipient/donor pair 4

$\begin{array}{rcc}-6 & 6.4 / 3.2 & 0 / 0 \\ 0 & \text { ND/4.8 } & \text { ND/30 } \\ 11 & 32 / \mathrm{ND} & \\ 18 & 155 / \mathrm{ND} & \\ 30 & 154 / \mathrm{ND} & \\ 48 & 158 / 23 & \end{array}$

Recipient/donor pair 5

$\begin{array}{rcc}-6 & 62 / 54 & 0 / 0 \\ 0 & \text { ND/123 } & \text { ND/720 } \\ 6 & 164 / \mathrm{ND} & \\ 13 & 157 / \mathrm{ND} & \\ 18 & 154 / \mathrm{ND} & \\ 25 & 144 / \mathrm{ND} & \end{array}$

Recipient/donor pair 6

\begin{tabular}{cccc}
-6 & $118 / 1.3$ & ND/0 & ND/0 \\
0 & ND/16 & ND/152 & ND/0 \\
14 & $336 / \mathrm{ND}$ & & \\
51 & $256 / 187$ & & \\
58 & $208 / \mathrm{ND}$ & & \\
75 & $199 / \mathrm{ND}$ & & \\
\multicolumn{1}{l}{ Recipient/donor pair 7} & & \\
-7 & $14 / 29$ & $0 / 0$ & $0 / 1.6$ \\
0 & ND/43 & ND/752 & ND/0 \\
7 & $50 / \mathrm{ND}$ & & \\
13 & $112 / \mathrm{ND}$ & & \\
22 & $73 / \mathrm{ND}$ & & \\
29 & $69 / \mathrm{ND}$ & & \\
Recipient/donor pair 9 & & ND/0 \\
-7 & $8.6 / 3.2$ & ND/0 & \\
0 & $8.6 / 4.7$ & ND/102 & \\
10 & $23 / \mathrm{ND}$ & & \\
19 & $54 / \mathrm{ND}$ & & \\
26 & $52 / 16$ & & \\
\hline
\end{tabular}

ND, not done.
Table III. Serum and In Vitro Antidiphtheria Toxoid Antibody Response in the Recipient/Donor

Pairs after Booster Immunization of the Donor 6-7 $d$ before Bone Marrow Transplantation

\begin{tabular}{rrrr}
\hline Day & $\begin{array}{l}\text { Serum IgG } \\
\text { antidip } \\
\text { recipient/donor }\end{array}$ & $\begin{array}{l}\text { Lymphoblastoid IgG } \\
\text { antidip } \\
\text { recipient/donor }\end{array}$ & $\begin{array}{l}\text { PWM inducible IgG } \\
\text { antidip } \\
\text { recipient/donor }\end{array}$ \\
\hline & $\mu g / m l$ & ng/culture & $n g /$ culture \\
\multicolumn{2}{l}{ Recipient/donor pair 1} & & \\
-6 & $11.3 / 9.3$ & $0 / 0$ & $0 / 0$ \\
0 & $\mathrm{ND} / 15.6$ & $\mathrm{ND} / 32.5$ & $\mathrm{ND} / 0$ \\
14 & $60.2 / \mathrm{ND}$ & & \\
29 & $123.2 / 72$ & &
\end{tabular}

Recipient/donor pair 3

$\begin{array}{rc}-6 & 14.4 / 17.0 \\ 0 & \text { ND/18.7 } \\ 5 & 10.1 / \mathrm{ND} \\ 12 & 24.1 / \mathrm{ND} \\ 19 & 49.5 / \mathrm{ND} \\ 27 & 49.1 / \mathrm{ND} \\ 33 & 34.9 / 78.6\end{array}$

$0 / 0 \quad 0 / 0$

$\mathrm{ND} / 10.3 \quad \mathrm{ND} / 0$

Recipient/donor pair 4

$-6 \quad 11.9 / 14.8$

$0 \quad \mathrm{ND} / 16.7$

$11 \quad 51.2 / \mathrm{ND}$

$\begin{array}{cr}0 / 0 & 0 / 0 \\ \mathrm{ND} / 195 & \mathrm{ND} / 0\end{array}$

Recipient/donor pair 5

$\begin{array}{rrcr}-6 & 7.6 / 10.0 & 0 / 0 & 0 / 0 \\ 0 & \mathrm{ND} / 15.7 & \mathrm{ND} / 130 & \mathrm{ND} / 0 \\ 25 & 76.5 / 39.6 & & \end{array}$

Recipient/donor pair 6

$\begin{array}{rlll}-6 & 20.2 / 5.0 & \mathrm{ND} / 3.4 & \mathrm{ND} / 0 \\ 0 & \mathrm{ND} / 11.2 & \mathrm{ND} / 10.0 & \mathrm{ND} / 0 \\ 14 & 49.7 / 26.6 & & \\ 51 & 19.4 / 11.0 & & \\ 58 & 16.1 / \mathrm{ND} & & \end{array}$

Recipient/donor pair 7

\begin{tabular}{|c|c|c|c|}
\hline-7 & $10.9 / 3.2$ & $0 / 0$ & $0 / 1.2$ \\
\hline $\mathbf{0}$ & $\mathrm{ND} / 7.5$ & $\mathrm{ND} / 51$ & $\mathrm{ND} / 22.0$ \\
\hline 7 & 24.4/ND & & \\
\hline \multicolumn{4}{|c|}{ Recipient/donor pair 9} \\
\hline-7 & $2.3 / 9.7$ & $\mathrm{ND} / 0$ & $\mathrm{ND} / 0$ \\
\hline $\mathbf{0}$ & $2.1 / 14.1$ & $\mathrm{ND} / 15.9$ & $\mathrm{ND} / 0$ \\
\hline 10 & $12.4 / \mathrm{ND}$ & & \\
\hline
\end{tabular}

ND, not done.

onstrated the expected serum antitet responses. All seven recipients showed a rise in serum antitet antibody within the first month after transplantation. The magnitude of this response varied from 2.9- to 90-fold with peak increases of antibody from 46 to $217 \mu \mathrm{g} / \mathrm{ml}$. Antidip antibody responses were observed in all donor/recipient pairs. Although the magnitude of these antidip responses was less than the antitet response, the responses in the recipients and donors were not appreciably different. The lower antibody response to dip toxoid likely represents a differ- 
ence in the human response to dip versus tet toxoids as employed. We have observed this discrepancy in previous studies (21).

There was no correlation between the donors' preimmunization antitet level and the magnitude of the increase in IgG antitet observed in the recipient. Similarly, the recipients' posttransplant increase in serum IgG antitet was unrelated to the absolute level of spontaneous IgG antitet cells detected in the transplanted bone marrow. It was also unrelated to the increase in IgG antitet detected in the donor's serum at the time of transplantation.

One possible explanation for the rise in specific antibody in the recipients is as a result of antibody passively transferred via blood component transfusions. The blood products received by the patients during the time period of study are tabulated in Table IV. This is informative in a number of cases. Recipient 4 did not receive any blood products between days 11 and 18 while there was a marked rise in tet antibody. Recipient 1 received only a single-donor plateletpheresis transfusion between days -6 and 14 and had a large rise in antibody; between days 14 and 29 he received large quantities of blood components with little change in tet antibody. Similarly in recipient 5 , the marked rise in antibody seen before day 13 was associated with administration of few blood product transfusions. In recipient 3 , there was a marked rise in antitet and antidip between days 5 and 12 when only 1 unit of packed red blood cells was given.

Sera were obtained from three similar transplant recipients who received a transplant from donors who had not been specifically immunized before transplantation. As with the immunized pairs, these donors had not received a tet/dip booster in the preceding $6 \mathrm{mo}$. In the month after transplant, these recipients showed no rise in serum antitetanus IgG $>1.5$-fold. The maximum quantitative increase in antitet antibody posttransplant was $10.6 \mu \mathrm{g} / \mathrm{ml}(5.6-6.3 \mu \mathrm{g} / \mathrm{ml}, 60.1-51.7 \mu \mathrm{g} / \mathrm{ml}$, and $21.4-$ $32.0 \mu \mathrm{g} / \mathrm{ml}$ ).

Response to reimmunization in bone marrow transplantation recipients. Three transplant recipients underwent a single booster immunization with tet/dip toxoids 64-154 days posttransplant (Table V). 7-8 d later, antitet lymphoblastoid cells were detected in the blood of these patients, and there was a subsequent rise in serum antitet levels within $28 \mathrm{~d}$ of immunization. In contrast, B cells spontaneously producing substantial IgG antidip were detected in only one individual (no. 7), and this recipient alone went on to produce a serum IgG antidip in response to the immunization. Both recipients 5 and 7 had low but detectable levels of PWM-inducible antibody responses, particularly to dip; these cells were detected prior to immunization and likely represented the PWM-inducible cells that developed after the initial immunization of that immune system (in the donor) pretransplant (13). The presence of these mitogen-reactive cells, however, did not correlate with the subsequent development of antibody to tet or dip after recipient immunization.

Three bone marrow transplant recipients, whose donors had not been specifically immunized, were given a tet/dip immunization at days 88,113 , and 715 , respectively, after transplantation. Two had acute myelogenous leukemia and one had lymphocytic lymphoma, all three received standard conditioning and maintenance, and none had cytomegalovirus infection. The recipients, who were 88 and 113 d posttransplant, made no lymphoblastoid cell response and no serum antibody over the subsequent $21 \mathrm{~d}$. The IgG antitet went from 15.9 to $15.7 \mu \mathrm{g} / \mathrm{ml}$ in one and from 18.8 to $18.7 \mu \mathrm{g} / \mathrm{ml}$ in the other. The patient who was $715 \mathrm{~d}$ posttransplant showed a minimal spontaneous IgG
Table IV. Blood Products Administered to Recipients during Study Period

\begin{tabular}{|c|c|c|}
\hline Recipient & Days & Products received \\
\hline \multirow[t]{5}{*}{1} & -6 to 13 & 1 plateletpheresis* \\
\hline & 14 to 29 & 4 plateletpheresis \\
\hline & & $5 \mathrm{U}$ fresh frozen plasma \\
\hline & & $6 \mathrm{U}$ packed red cells \\
\hline & & $5 \mathrm{U}$ platelets \\
\hline \multirow[t]{4}{*}{3} & -6 to 5 & 0 \\
\hline & 5 to 12 & $1 \mathrm{U}$ packed red cells \\
\hline & 13 to 19 & $1 \mathrm{U}$ packed red cells \\
\hline & 19 to 33 & 0 \\
\hline \multirow[t]{3}{*}{4} & -6 to 11 & $5 \mathrm{U}$ packed red cells \\
\hline & 11 to 18 & 0 \\
\hline & 19 to 48 & $2 \mathrm{U}$ packed red cells \\
\hline \multirow[t]{4}{*}{5} & -6 to 6 & $5 \mathrm{U}$ platelets \\
\hline & 7 to 13 & 3 plateletpheresis \\
\hline & & $4 U$ packed red cells \\
\hline & 14 to 25 & $2 \mathrm{U}$ packed red cells \\
\hline \multirow[t]{5}{*}{6} & -6 to 14 & 2 plateletpheresis \\
\hline & 15 to 51 & $10 \mathrm{U}$ packed red cells \\
\hline & & 3 plateletpheresis \\
\hline & 51 to 75 & $14 \mathrm{U}$ packed red cells \\
\hline & & 75 U platelets \\
\hline \multirow[t]{9}{*}{7} & -7 to 7 & 3 plateletpheresis \\
\hline & & 1 white blood cell pheresis \\
\hline & & $5 \mathrm{U}$ platelets \\
\hline & 8 to 13 & 2 plateletpheresis \\
\hline & & $2 \mathrm{U}$ packed red cells \\
\hline & & 1 white blood cell pheresis \\
\hline & 14 to 22 & 1 plateletpheresis \\
\hline & & $5 \mathrm{U}$ platelets \\
\hline & 23 to 29 & $2 \mathrm{U}$ packed red cells \\
\hline \multirow[t]{6}{*}{9} & -7 to 10 & 1 plateletpheresis \\
\hline & & $10 \mathrm{U}$ platelets \\
\hline & & $2 \mathrm{U}$ packed red cells \\
\hline & 11 to 19 & 2 plateletpheresis \\
\hline & & $2 U$ packed red cells \\
\hline & 20 to 26 & $2 \mathrm{U}$ packed red cells \\
\hline
\end{tabular}

* Plateletpheresis, single-donor plateletpheresis.

antitet cell response at day 7 and her antitet IgG rose from 6.3 to $12.5 \mu \mathrm{g} / \mathrm{ml}$. No antidip response was seen in any of these recipients.

IgM antitetanus antibody response. The IgM antitet antibody response was studied in six donor/recipient pairs (Table VI). Prior to booster immunization, five of six donors had PWMreactive antitet IgM-reactive cells in the blood (17). Cells spontaneously synthesizing IgM antitet were not found in the blood in this or any prior study. After immunization, transplanted bone marrow cells from five of the donors demonstrated cells spontaneously producing antitet IgM. An IgM antitet serum response of twofold or greater was observed in these five donors; however, the increases were low with a maximum rise of 3.1fold. In contrast, only one recipient showed an increase of serum 
Table V. IgG Response to Immunization after Bone Marrow Transplantation in Recipients with Adoptively

Transferred Tetanus/Diphtheria Toxoid Antibody Response

\begin{tabular}{|c|c|c|c|c|}
\hline Recipient & Day* & $\begin{array}{l}\text { Serum } \\
\text { antitet/dip }\end{array}$ & $\begin{array}{l}\text { Lymphoblastoid } \\
\text { antitet/dip }\end{array}$ & $\begin{array}{l}\text { PWM inducible } \\
\text { antitet/dip }\end{array}$ \\
\hline & & $\mu g / m l$ & ng/culture & ng/culture \\
\hline \multirow[t]{3}{*}{3} & $0(154)$ & $12.8 / 6.1$ & $0 / 0.5$ & $0 / 0$ \\
\hline & 8 & $15.4 / 6.6$ & $80 / 0$ & $0 / 0.4$ \\
\hline & 22 & $108 / 5.9$ & & \\
\hline \multirow[t]{3}{*}{5} & $0(124)$ & $28.8 / 26$ & $0 / 0$ & $4 / 5.8$ \\
\hline & 7 & $63.9 / \mathrm{ND}$ & $22 / 2.7$ & $0 / 2.7$ \\
\hline & 28 & $92.8 / 9.6$ & ND & ND \\
\hline \multirow[t]{3}{*}{7} & $0(64)$ & $23.1 / 18$ & $0 / 0$ & $0 / 2.3$ \\
\hline & 7 & $76.2 / 32$ & $15 / 17.0$ & $0 / 3.5$ \\
\hline & 21 & $88.6 / \mathrm{ND}$ & ND & ND \\
\hline
\end{tabular}

* Days postimmunization of the recipient while the number in parentheses is the days after bone marrow transplantation.

IgM antitet of greater than twofold after receiving bone marrow from a booster immunized donor. Note that the level of these IgM responses were some 100-1,000-fold less than the IgG responses. These are the levels of serum IgM response seen in previously immunized normals (17).

Spectrotypic analysis of antidiphtheria fragment $A$ antibody responses. We next sought to determine, at the clonal level, how closely the antibody response in the recipients paralleled that seen in their individual donors. Serum was obtained from five donor/recipient pairs and analyzed for the spectrotypic pattern of the antidip fragment A response present prior to and at various times after immunization. Antibody was separated by IEF and the bands of anti-fragment $A$ antibody visualized by binding of radiolabeled fragment $A$ followed by autoradiography.

We have previously shown that analytical IEF of sera from normal persons who had been booster immunized with dip toxoid is capable of detecting discrete clones of antibodies. This is especially true when only the fragment A portion of dip toxin is employed as the developing antigen. Sample anti-fragment A antibody spectrotype patterns from 14 immunized normals are shown in Fig. 1. The majority of individuals show restriction to one or two antibody clones with each clone being characterized by a series of three to five closely spaced bands.

In three donor/recipient pairs, the clonotype pattern seen in the recipient paralleled that seen in the donor. In donor/recipient pair 1, similar spectrotypes were observed after immunization and transplantation. Prior to immunization, neither donor nor recipient serum contained detectable anti-fragment $A$ antibodies (Fig. 2, lanes $C$ and $D$ ). After immunization, the donor produced a very polyclonal anti-fragment $\mathrm{A}$ antibody response (Fig. 2, lane $A$ ) and this same pattern was seen in the recipient (Fig. 2, lane $B$ ). While the polyclonality of this response makes identification of individual clones difficult, there was clear pattern similarity. Additionally, both donor and recipient demonstrated the presence of anti-fragment $A$ antibodies in the acidic portion of the gel. This is an unusual finding, having been observed in only $5 \%$ of a large number of donors (20). In donor/recipient pair 5 , the donor also made a heterogeneous response to fragment
Table VI. Serum and In Vitro IgM Antitetanus Toxoid Response from the Recipient and Donor after Booster Immunization of the Donor 6-7 $d$ before Bone Marrow Transplantation

\begin{tabular}{|c|c|c|c|}
\hline Day & $\begin{array}{l}\text { Serum IgM } \\
\text { antitet } \\
\text { recipient/donor }\end{array}$ & $\begin{array}{l}\text { Lymphoblastoid IgM } \\
\text { antitet } \\
\text { recipient/donor }\end{array}$ & $\begin{array}{l}\text { PWM inducible IgM } \\
\text { antitet } \\
\text { recipient/donor }\end{array}$ \\
\hline & $n g / m l$ & ng/culture & ng/culture \\
\hline \multicolumn{4}{|c|}{ Recipient/donor pair 3} \\
\hline-6 & $48 / 120$ & ND/0 & $0 / 8.6$ \\
\hline 0 & $45 / 126$ & $\mathrm{ND} / 4.3$ & ND/9.5 \\
\hline 5 & $36 / \mathrm{ND}$ & & \\
\hline 12 & 48/ND & & \\
\hline 19 & 108/ND & & \\
\hline 27 & 204/ND & & \\
\hline 33 & $240 / 377$ & & \\
\hline \multicolumn{4}{|c|}{ Recipient/donor pair 4} \\
\hline-6 & $361 / 172$ & $0 / 0$ & $0 / 0$ \\
\hline 0 & $\mathrm{ND} / 416$ & $\mathrm{ND} / 28.1$ & $\mathrm{ND} / 4.2$ \\
\hline 11 & 474/ND & & \\
\hline 18 & $540 / \mathrm{ND}$ & & \\
\hline 30 & 444/ND & ' & \\
\hline 48 & $416 / \mathrm{ND}$ & & \\
\hline \multicolumn{4}{|c|}{ Recipient/donor pair 5} \\
\hline-6 & $426 / 125$ & $0 / 0$ & $12.0 / 3.1$ \\
\hline 0 & $\mathrm{ND} / 264$ & $\mathrm{ND} / 125.8$ & ND/0.6 \\
\hline 6 & $460 / \mathrm{ND}$ & & \\
\hline 13 & $456 / \mathrm{ND}$ & & \\
\hline 18 & $516 / \mathrm{ND}$ & & \\
\hline 25 & $408 / \mathrm{ND}$ & & \\
\hline \multicolumn{4}{|c|}{ Recipient/donor pair 6} \\
\hline-6 & $768 / 630$ & $\mathrm{ND} / 0$ & $\mathrm{ND} / 3.1$ \\
\hline 0 & $\mathrm{ND} / 568$ & $\mathrm{ND} / 1.2$ & $\mathrm{ND} / 1.0$ \\
\hline 14 & $690 / \mathrm{ND}$ & & \\
\hline 51 & $528 / \mathrm{ND}$ & & \\
\hline 58 & $492 / 528$ & & \\
\hline 75 & $552 / \mathrm{ND}$ & & \\
\hline \multicolumn{4}{|c|}{ Recipient/donor pair 7} \\
\hline-7 & $481 / 166$ & $\mathrm{ND} / 0$ & $\mathrm{ND} / 4.8$ \\
\hline 0 & $\mathrm{ND} / 390$ & $\mathrm{ND} / 60.2$ & $\mathrm{ND} / 1.7$ \\
\hline 7 & $512 / \mathrm{ND}$ & & \\
\hline 13 & $840 / \mathrm{ND}$ & & \\
\hline 22 & 504/ND & & \\
\hline 29 & 602/ND & & \\
\hline \multicolumn{4}{|c|}{ Recipient/donor pair 9} \\
\hline-7 & $744 / 156$ & ND/0 & $\mathrm{ND} / 10.2 ?$ \\
\hline 0 & $\mathrm{ND} / 251$ & $\mathrm{ND} / 102$ & $\mathrm{ND} / 0$ \\
\hline 10 & $624 / \mathrm{ND}$ & & \\
\hline 19 & $488 / \mathrm{ND}$ & & \\
\hline 26 & $504 / 128$ & & \\
\hline
\end{tabular}

ND, not done.

A and this was transferred to the recipient (Fig. 3). Unlike donor/ recipient pair 1 , there was a well-defined spectrotype clone (near pI 7.5) that was transferred to the recipient and this spectrotype persisted. 


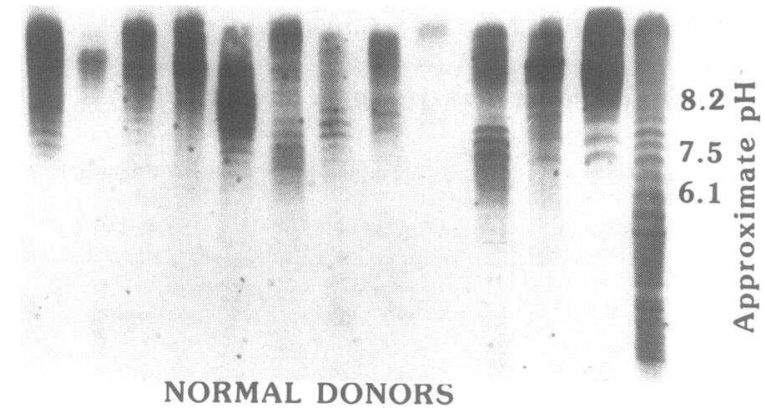

Figure 1. Spectrotypic analysis of anti-fragment A antibodies in normal individuals. Serum from normal persons who had been immunized with dip toxiod 2-3 wk earlier were prepared and analyzed by IEF as described in Methods. After incubation with iodinated fragment $A$, the gels were washed and dried, and autoradiographs were prepared.

After immunization of the recipient, spectrotype analysis in one patient/donor pair was informative. The donor in pair 3 produced a single anti-fragment $\mathrm{A}$ antibody clonotype characterized by three to four antibody bands near pI 8.2 (Fig. $4 \mathrm{~A}$ ). For $32 \mathrm{~d}$ after transplantation, the recipient failed to show a resolvable pattern (Fig. $4 \mathrm{~B}$ ) but subsequently developed a recognizable pattern by day 146 . After immunization of this recipient (day 154), this anti-fragment A clone became selectively amplified versus other potential anti-fragment $A$ clones, as assessed by IEF with equal amounts of serum obtained on day 168 (Fig. $4 \mathrm{~B}$ ) where increased amounts of serum were added to fully display the patterns.

\section{Discussion}

We previously studied the in vitro function and the sequence of appearance of spontaneous and mitogen-reactive antibodyproducing $B$ cell subsets in the blood and bone marrow after booster immunization with tet/dip toxoids (17). Using the difference in time of appearance of these subsets in the bone mar-

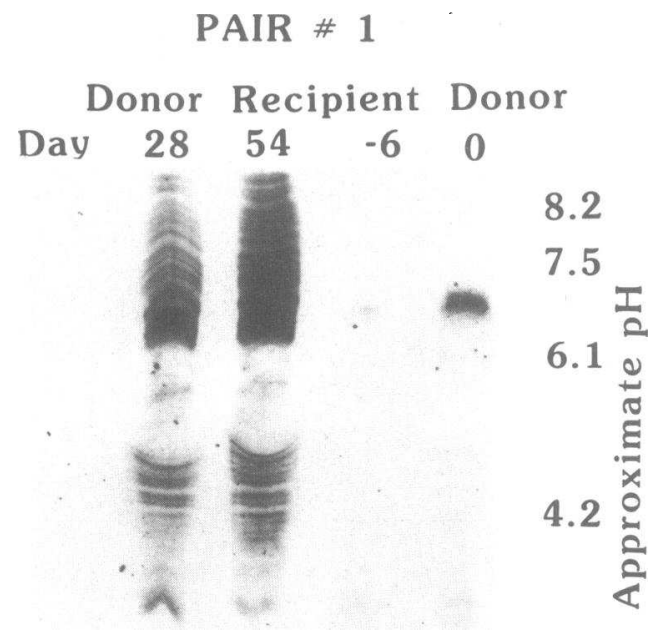

Figure 2. Anti-fragment A antibody spectrotype from donor/recipient pair 1 . Serum was obtained from the donor (day 0 ) and recipient (day -6) prior to transplantation and from the donor (day 54) and recipient (day 28) posttransplantation.

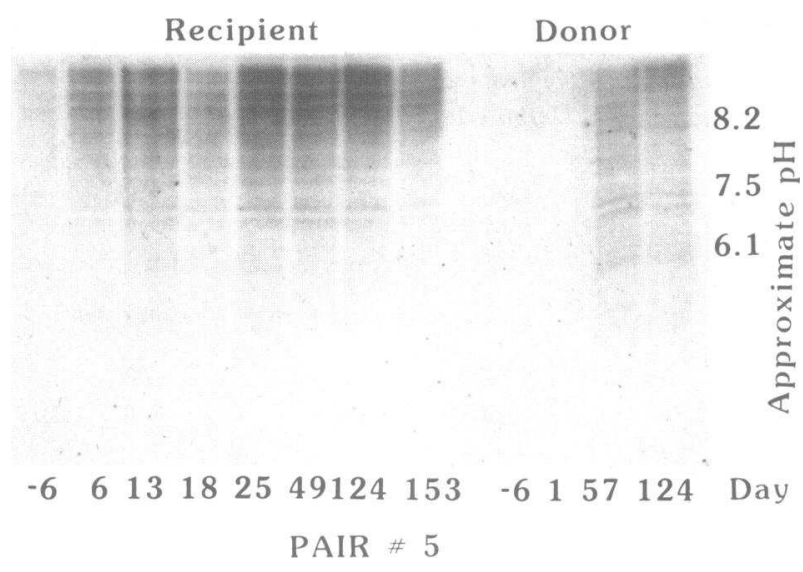

Figure 3. Transfer of the anti-fragment A spectrotype response pattern in donor/recipient pair 5. Sera were obtained prior to and at the indicated times posttransplantation. Sera were analyzed as described. Note the similar two-band spectrotype pattern in the donor and recipient near $\mathrm{pI} 7.5$.

row, we demonstrated specific transfer of B cells spontaneously synthesizing IgG and IgM antitet and IgG antidip antibodies to bone marrow transplant recipients. A rise in IgG antitet and IgG antidip antibodies was observed in every recipient (Tables II and III). This finding was correlated with the presence of spontaneous antibody-producing $B$ cells in the donor bone marrow graft while PWM-reactive antigen-specific B cells were absent. Furthermore, recipients of transplants from non-boosted donors failed to demonstrate more than a 1.5-fold rise in IgG antitet or antidip arguing against the incidental transfer of tetanus reactivity. Our findings suggest that such transfer will occur if a donor has been recently immunized by medical or natural antigen exposure if such exposure leads to the presence of specific antibody-secreting cells in the marrow at the time of transplantation. Recently, Wimperis et al. (22) reported very similar findings in that immunization of bone marrow transplant donors with tetanus toxoid or hepatitis B vaccine induced spontaneous antibody-forming cells in the marrow at the time of transfer and the recipients went on to make serum IgG antibody responses. They were able to accomplish this with $\mathrm{T}$ cell-depleted marrow.

Of note, the recipients' antibody levels were equivalent to those in normals undergoing booster immunization. In addition, the responses were detectable as early as $5 \mathrm{~d}$ and were generally maximum between 2 and 4 wk posttransplantation (11-34 d after the donors were booster immunized). Thus antibody responses were often detected before complete hematopoietic engraftment was evident. These serum antibody responses could not be explained by passive transfer associated with blood products. To affect a rise of $100 \mu \mathrm{g}$ of IgG antitet, $2 \mathrm{U}$ of whole blood would each have to contain $1 \mathrm{~g}$ of antibody: 5-10 times the level of antibody seen in boosted individuals. Furthermore, some patients (i.e., nos. 1, 3, 4, 5, and 6), had a clear rise in antibody titers when no or little blood products were given.

Analysis by IEF of spectrotypes of antidip fragment $A$ in several donor/recipient pairs revealed the development of identical spectrotypic patterns of antibody responses from the donor $B$ cells in both the donor and recipient. Thus, while Wahren et al. (23) suggested the persistence of recipient antiviral antibody production for several months posttransplantation, we demonstrated that the antibody responses that we observed were the results from the adoptive transfer of donor-specific immune re- 
PAIR \#3

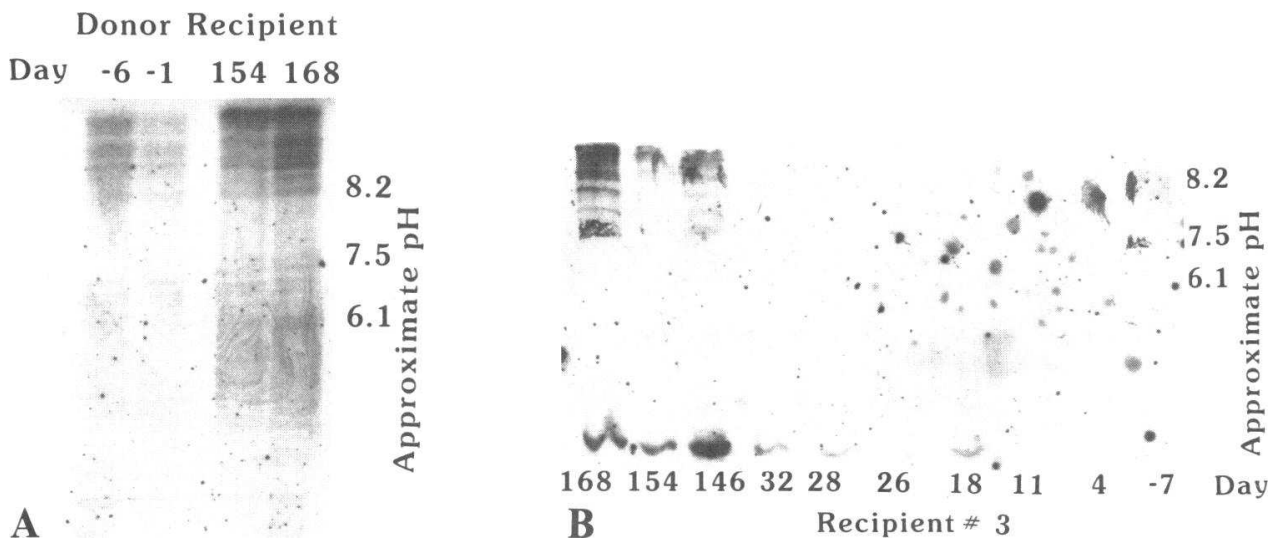

Figure 4. Demonstration of the same spectrotype in donor/recipient pair 3 after immunization of the recipient at day 154 posttransplantation. ( $A$ ) Antidip fragment A response in donor serum obtained on days -1 and -6 before transplantation and the Recipients' serum on days 154 and 168 posttransplantation. (B) Spectrotype pattern in the recipient's serum over the time period from day -6 to day 168 posttransplantation. The recipient received a tet/dip immunization on day 154 .

sponses to tet and dip toxoids. This is consistent with data that immunoglobulin produced in bone marrow transplant recipients is of donor origin (6).

These studies indicate the feasibility of purposely transferring to bone marrow transplant recipients a fully developed IgG antibody response which is established very early after transplantation. We feel this rapid adoptive transfer of humoral immunity probably results from the ongoing proliferation and differentiation of spontaneous IgG antibody-producing donor B cells: cells that can be intentionally induced in the donor marrow. We have previously demonstrated that a limited number of these lymphoblastoid B cells have the potential, during in vitro culture, to give rise to antibody-secreting cells as well as cells that do not immediately secrete antibody (24). It is therefore possible that these lymphoblastoid cells can both provide for immediate antibody synthesis as well as for generation of a memory response. Although spontaneous IgM antitet producing cells were present in donor bone marrows in five of six pairs, only one recipient demonstrated a twofold or greater rise in IgM antitet (Table VI); this is typical of secondary antibody responses.

To determine whether we also transferred immune memory, three recipients received a booster immunization 64,124 , and $154 \mathrm{~d}$ posttransplant (Table V). All three had a rapid rise in IgG antitet associated with the appearance of B cells spontaneously producing IgG antitet; this is characteristic of a secondary antibody response. Only one recipient made an IgG antidip response as measured by enzyme-linked immunosorbent assay (ELISA); this was associated with spontaneous antibody production to dip in vitro. The reason why only one of three recipients responded to dip immunization is unknown. There is less dip than tet antigen in the combined booster and adults are far more likely to have had multiple and more recent immunizations to tet. Furthermore, the difference in the molecular weights of tet toxoid $(160,000)$ versus dip toxoid $(60,000)$ may be responsible. Analysis of antidip fragment $A$ antibodies in these same sera revealed responses in two recipients. This occurs because the anti-fragment $A$ antibody comprises a small percentage of the total antidip response and may rise sharply without making a significant change in the total antidip antibody level. Analysis of the spectrotype of the antidip fragment $A$ in the responding recipients was particularly informative, revealing the development of the donor spectrotype. These data strongly suggest the transfer of specific immune memory which was expressed upon immunization of the recipient posttransplant. These antitet and antidip antibody responses were elicited within the first 5 mo after transplantation, a time at which recipients of transplants from nonimmunized donors failed to make specific antibody responses.

Thus, by transfer of B cells spontaneously synthesizing specific antibody (lymphoblastoid B cells), we were able to transfer specific immunologic memory in addition to an active adoptive antibody response. These findings are in accord with extensive studies in murine models where it has been known for many years that specific antibody can be transferred with spleen and bone marrow and that donor immunization influences the reconstitution of specific humoral immunity in the recipient (2528). Since PWM-reactive antigen-specific $B$ cells were not present in the donor bone marrow (Table II) or at the time of reimmunization (Table V), it is unlikely that such cells are directly involved in the memory response. It is possible that PWM-reactive cells play a role in the development of B cell memory; however, they must appear at times other than those we studied. Two cases of possible inadvertent transfer of specific IgE memory responses by marrow transplantation have been reported, however the data were not definitive $(29,30)$.

There is a prolonged period of severe cellular and humoral immunodeficiency after bone marrow transplantation. Although the number of $B$ cells in the blood usually normalizes by the third month, IgG and IgM levels do not return to normal until 4-6 mo posttransplant. IgA levels remain depressed for a year or more. Qualitative function of humoral immunity, particularly to T-dependent antigens, remains depressed for prolonged periods. Witherspoon and co-workers reported that responses to phage 0174 are depressed for more than $3-4$ mo $(7,8)$. They also demonstrated a failure in the switch from IgM to IgG antibodies in response to this antigen. Responses to pneumococcal polysaccaride are depressed for more than 7 mo (31). Humoral responses to tetanus do not normalize until 1 yr or more. This suppression of antibody responses is similar whether cyclosporine or methotrexate is used for posttransplant immunosuppression. The tempo of recovery of immune competence is adversely affected by GVHD and by CMV infection (11, 32-39). Similar problems exist with respect to recovery of $\mathrm{T}$ cell-mediated immunity $(20,24,31)$.

As a result, patients undergoing bone marrow transplantation often develop severe or fatal infections in the first 6 mo after transplantation. CMV is one of the most important pathogens and accounts for approximately half of the mortality in recipients 
within 6 mo of transplant. Prophylaxis with large amounts of CMV-immune gammaglobulin has been shown to modify CMV interstitial pneumonia but it is costly and not completely effective. Our study shows it is possible to design transfer of specific immunity from donor to recipient. Appropriate immunization of donors with vaccines may well provide to bone marrow transplant recipients protection against infections such as CMV.

Note Added in Proof. It has come to our attention that studies by F. L. Adler and L. T. Adler in rabbits (1984. Transplantation. 38:382-386; 1985. Cell. Immunol. 91:385-396) have given findings analogous to what we have reported.

\section{Acknowledgments}

The authors thank Aimee Nguyen, Birgitte Keld, and Kyoung Lee for excellent technical assistance and the physicians and nurses of the UCLA Bone Marrow Transplantation Unit for their care of these patients.

This study was supported in part by grants AI-15332, AI-15251, CA12800, CA-23175, CA-34899, and KO8CA00932 from the U. S. Public Health Service.

\section{References}

1. Gale, R. P. 1983. Recent Advances in Bone Marrow Transplantation. Alan R. Liss, Inc., New York.

2. Meyers, J. D., N. Flournoy, and E. D. Thomas. 1982. Nonbacterial pneumonia after allogeneic marrow transplantation: a review of 10 years experience. Rev. Infect. Dis. 4:1119-1126.

3. Atkinson, K., V. Farewell, R. Storb, M. S. Tsoi, K. M. Sullivan, R. P. Witherspoon, A. Fefer, R. Clift, B. Goodell, and E. D. Thomas. 1982. Analysis of late infections after human bone marrow transplantation: role of genotypic non identity between marrow donor and recipient and of non specific suppressor cells in patients with chronic graft-versushost disease. Blood. 60:714-720.

4. Fass, L., H. D. Ochs, E. D. Thomas, E. Mickelson, R. Storb, and A. Fefer. 1973. Studies of immunological reactivity following syngeneic or allogeneic marrow grafts in man. Transplantation. 16:630-639.

5. Gale, R. P., G. Opelz, M. R. Mickey, P. R. Graze, and A. Saxon. 1978. Immunodeficiency following allogeneic bone marrow transplantation. Transplant. Proc. 10:223-228.

6. Witherspoon, R. P., K. Kopecky, R. F. Storb, N. Flournoy, K. M. Sullivan, R. Sosa, H. J. Deeg, H. D. Ochs, M. A. Cheever, A Fefer, and E. D. Thomas. 1982. Immunological recovery in 48 patients following syngeneic marrow transplantation for hematological malignancy. Transplantation. 33:143-149.

7. Noel, D. R., R. P. Witherspoon, R. Storb, K. Atkinson, K. Doney, E. M. Mickelson, H. D. Ochs, R. P. Warren, P. L. Weiden, and E. D. Thomas. 1978. Does graft-versus-host disease influence the tempo of immunologic recovery after allogeneic human marrow transplantation? An observation on 56 long-term survivors. Blood. 51:1087-1105.

8. Witherspoon, R. P., R. Storb, H. D. Ochs, N. Flournoy, K. J. Kopecky, K. M. Sullivan, H. J. Deeg, R. Sosa, D. R. Noel, K. Atkinson, and E. D. Thomas. 1981. Recovery of antibody production in human allogeneic marrow graft recipients: Influence of time posttransplantation, the presence or absence of chronic graft-versus-host disease, and antithymocyte globulin treatment. Blood. 58:360-368.

9. Witherspoon, R. P., L. G. Lum, and R. Storb. 1984. Immunologic reconstitution after human marrow grafting. Semin. Hematol. 21:1-12.

10. Pahwa, S. G., R. N. Pahwa, W. Freidrich, R. J. O'Reilly, and R. A. Good. 1982. Abnormal humoral immune responses in peripheral blood lymphocyte cultures of bone marrow transplant recipients. Proc. Natl. Acad. Sci. USA. 79:2663-2667.

11. Schroff, R. W., R. P. Gale, and J. L. Fahey. 1982. Regeneration of $\mathrm{T}$ cell subpopulations after bone marrow transplantation: cytomeg- alovirus infection and lymphoid subset imbalance. J. Immunol. 129: 1926-1930.

12. Gratama, J. W., A. Naipal, P. Oljans, F. E. Zwaan, L. F. Verdonck, T. de Witte, J. M. J. J. Vossen, R. L. H. Bolhuis, G. C. de Gast, and J. Jansen. 1984. T Lymphocyte repopulation and differentiation after bone marrow transplantation. Early shifts in the ratio between T4+ and T8+ $\mathrm{T}$ lymphocytes correlate with the occurrence of acute graft-versus-host disease. Blood. 63:1416-1423.

13. Stevens, R. H., and A. Saxon. 1978. Immunoregulation in humans. Control of antitetanus toxoid antibody production after booster immunization. J. Clin. Invest. 62:1154-1160.

14. Stevens, R. H., and A. Saxon. 1979. Differential synthesis of IgM and IgG anti-tetanus antibody in vitro and following in vivo booster immunization of humans. Cell. Immunol. 45:142-150.

15. Stevens, R., E. Macy, C. Morrow, and A. Saxon. 1979. Characterization of circulation subpopulations of spontaneous antitetanus toxoid antibody producing B cells following in vivo booster immunization. J. Immunol. 122:2498-2503.

16. Stevens, R. H., M. Tamaroff, and A. Saxon. 1980. Inability of patients with common variable hypogammaglobulinemia to generate lymphoblastoid B cells following booster immunization. Clin. Immunol. Immunopathol. 16:336-343.

17. Kodo, H., R. P. Gale, and A. Saxon. 1984. Antibody synthesis by bone marrow cells in vitro following primary and booster tetanus toxoid immunization in humans. J. Clin. Invest. 73:1377-1384.

18. Morrow, C. D., E. M. Macy, and R. H. Stevens. 1981. Analysis of antidiphtheria antibodies by isoelectric focusing: evidence for restricted clonal heterogeneity of anti-fragment A antibodies. Infect. Immun. 31: 1132-1139.

19. Gill, D. M., and L. L. Dinius. 1971. Observations on the structure of diphtheria toxin. J. Biol. Chem. 246:1485-1490.

20. Morrow, C. D., F. Dorey, and R. H. Stevens. 1983. Isoelectric focusing of human anti-diphtheria toxoid antibodies: identical spectrotypes of anti-fragment $A$ antibodies with the same IgG subclass and light chain constant regions are expressed in multiple individuals. J. Immunol. 130:818-823.

21. Morrow, C. D., E. M. Macy, and R. H. Stevens. 1981. Analysis of antidiphtheria antibodies by isoelectric focusing: evidence for restricted clonal heterogeneity of anti-fragment A antibodies. Infect. Immun. 31: 1132-1137.

22. Wimperis, J. Z., H. G. Prentice, P. Karayiannis, M. K. Brenner, J. E. Reittie, P. D. Griffiths, and A. V. Hoffbrand. 1986. Transfer of a functioning humoral immune system in transplantation of T-lymphocytedepleted bone marrow. Lancet. i:339-343.

23. Wahren, B., G. Gahrton, A. Linda, P. Ljungman, B. Lonnqvist, O. Ringden, and V. A. Sundqvist. 1984. Transfer and persistence of viral antibody-producing cells in bone marrow transplantation. Infect. Dis. 150:358-365

24. Brieva, J. A., and R. H. Stevens. 1984. Human in vivo antigeninduced lymphoblastoid B cells are capable of cyclical antibody production in vitro. J. Immunol. 133:147-153.

25. Gengozian, N., T. Makinodan, and I. C. Shekarchi. 1961. Transplantation of antibody forming cells in lethally irradiated mice. J. Immunol. 86:113-122.

26. Stoner, R. D., and V. P. Bond. 1963. Antibody formation by transplanted bone marrow, spleen, lymph nodes and thymus cells in irradiated recipients. J. Immunol. 91:185-196.

27. Garver, R. M., G. Santos, and L. J. Cole. 1959. Specific hemagglutinins in x-irradiated, bone marrow treated mice following immunization of host and donor. J. Immunol. 83:57-65.

28. Chin, P. H., and M. S. Silverman. 1960. Studies on the transfer of antibody formation by 150 - and heterotransplants. J. Immunol. 85 : 120-129.

29. Saarinen, U. M. 1984. Transfer of latent atopy by bone marrow transplantation? A case report. Allergy Clin. Immunol. 74:196-200.

30. Tucker, J., and R. St. C. Barnetson. 1985. Atopy after bone marrow transplantation. Br. Med. J. 290:116-117. 
31. Winston, D. J., W. G. Ho, G. Schiffman, E. Champlin, S. A. Feig, and R. P. Gale. 1983. Pneumococcal vaccination of recipients of bone marrow transplants. Arch. Intern. Med. 143:1753-1737.

32. Noel, D. R., R. P. Witherspoon, R. Storb, K. Atkinson, K. Doney, E. M. Mickelson, H. D. Ochs, R. P. Warren, P. L. Weiden, and E. D. Thomas. 1978. Does graft-versus-host disease influence the tempo of immunologic recovery after allogeneic human marrow transplantation? An observation on 56 long-term survivors. Blood. 51:6:1087-1105.

33. Friedrich, W., R. J. O'Reilly, B. Koziner, D. F. Gebhard, Jr., R. A. Good, and R. L. Evans. 1982. T-lymphocyte reconstitution in recipients of bone marrow transplants with and without GVHD: Imbalances of T-Cell subpopulations having unique regulatory and cognitive functions. Blood. 59:696-701.

34. Tsoi, M. S., R. Storb, S. Dobbs, K. J. Kopecky, E. Santos, P. L. Weiden, and E. D. Thomas. 1979. Nonspecific suppressor cells in patients with chronic graft-vs-host disease after marrow grafting. J. Immunol. 123:1970.

35. Saxon, A., R. E. McIntyre, R. H. Stevens, R. P. Gale. 1981.
Lymphocyte dysfunction in chronic graft-versus-host disease. Blood. 59: 696-701.

36. Lum, L. G., M. C. Seigneuret, R. Storb, R. P. Witherspoon, and E. D. Thomas. 1981. In vitro regulation of immunoglobulin synthesis after marrow transplantation: I. T-cell and B-cell deficiencies in patients with and without chronic graft-versus-host disease. Blood. 58:431-439.

37. Paulin, T., O. Ringden, and B. Lonnqvist. 1985. Faster Immunological recovery after bone marrow transplantation in patients without cytomegalovirus infection. Transplantation. 4:377-384.

38. Lum, L. G., M. C. Seigneuret, N. Orcutt-Thordarson, J. E. Noges, and $R$. Storb. 1984. The regulation of immunoglobulin synthesis after HLA-identical bone marrow transplantation. VI. differential rates of maturation of distinct functional groups within lymphoid subpopulations in patients after human marrow grafting. Blood. 65:6:1422-1433.

39. Witherspoon, R. P., D. Matthews, R. Storb, K. Atkinsion, M. Cheever, H. J. Deeg, K. Doney, J. Kalbfleisch, D. Noel, R. Prentice, K. M. Sullivan, and E. D. Thomas. 1984. Recovery of in vivo cellular immunity after human marrow grafting. Influence of time postgrafting and acute graft-versus-host disease. Transplantation. 37:2:145-150. 